\title{
Tanggung Jawab Pidana dalam Peristiwa Kecelakaan Lalu Lintas yang Korbanya Meninggal Dunia di Wilayah Hukum Resor Gianyar
}

\author{
Putu Ratih Mahalia Septiana ${ }^{1}$ \\ ${ }^{1}$ Program Studi Magister (S2) Kenotariatan Fakultas Hukum Universitas Udayana, \\ E-mail: ratihmahalia@gmail.com
}

\begin{tabular}{l}
\hline Info Artikel \\
\hline Masuk : 10 Agustus 2019 \\
Diterima : 17 September 2019 \\
Terbit : 30 Desember 2019 \\
Keywords: \\
Responsibility; Crime; and \\
Traffic Accidents. \\
\\
\\
Kata kunci: \\
Tanggung Jawab; Tindak \\
Pidana; dan Kecelakaan Lalu \\
Lintas \\
Corresponding Author: \\
Putu Ratih Mahalia Septiana \\
E-mail: \\
ratihmahalia@gmail.com \\
DOI : \\
10.24843/AC.2019.v04.i03.p15 \\
\end{tabular}

\begin{abstract}
The level of discipline and understanding of the rules and the low courtesy of traffic from road users is something that needs special attention in their efforts to solve problems in the field of traffic. The purpose of this study is as follows: to determine the legal consequences for perpetrators in traffic accidents whose victims have died and to find out legal considerations for perpetrators in criminal liability for traffic accidents. The type of research used is empirical juridical legal research. Results of the discussion in this study: The legal consequences for perpetrators in traffic accidents where the victim died was sentenced to a minimum prison sentence of 5 years. In accordance with Article 359 of the Criminal Code. Legal considerations for perpetrators in criminal liability for traffic accidents include unintentional elements (negligence), have never been convicted, there is peace between the parties, giving information is not convoluted, there are witnesses who are mitigating, then the threat of punishment can be lighter.

Abstrak

Tingkat disiplin dan pemahaman terhadap peraturan dan sopan santun berlalu lintas yang rendah dari para pemakai jalan merupakan hal yang perlu mendapatkan perhatian khusus dalam upaya pemecahannya untuk mengatasi permasalahan di bidang lalu lintas. Tujuan dari penelitian ini sebagai berikut: untuk mengetahui akibat hukum bagi pelaku dalam kecelakaan lalu lintas yang korbannya meninggal dunia dan untuk mengetahui pertimbangan hukum bagi pelaku dalam pertanggung jawaban pidana terhadap kecelakaan lalu lintas. Jenis penelitian yang dipergunakan adalah penelitian hukum yuridis empiris. Hasil pembahasan dalam penelitian ini: Akibat hukum bagi pelaku dalam kecelakaan lalu lintas yang korbannya meninggal dunia dipidana dengan hukuman penjara minimal 5 tahun. Sesuai Pasal 359 KUHP. Pertimbangan hukum bagi pelaku dalam pertanggung jawaban pidana terhadap kecelakaan lalu lintas antara lain ada unsur ketidaksengajaan (alpa), belum pernah dihukum, ada perdamaian diantara para pihak, memberikan keterangan tidak berbelit-belit, adanya saksi yang meringankan, maka ancaman hukuman bisa lebih ringan.
\end{abstract}




\section{Pendahuluan}

Untuk mengerti dan menghayati tujuan mulia dari Undang-Undang Nomor 22 Tahun 2009 tentang Lalu Lintas dan Angkutan Jalan, pemerintah khususnya Kepolisian Republik Indonesia telah mengambil langkah-langkah untuk memasyarakatkan undang-undang tersebut. Selanjutnya mengajak masyarakat luas untuk melaksanakan dan mematuhinya sehingga teratasi kendala-kendala yang ada selama ini.

Dalam penjelasan umum Undang-Undang Nomor 22 Tahun 2009 tentang Lalu Lintas dan Angkutan Jalan ditegaskan:

"Penajaman Formulasi mengenai asas dan tujuan dalam undang-undang ini, selain untuk menciptakan lalu lintas dan angkutan jalan yang aman, selamat, tertib, lancar, dan terpadu dengan moda angkutan lain, juga mempunyai tujuan untuk mendorong perekonomian nasional, mewujudkan kesejahteraan rakyat, persatuan dan kesatuan bangsa, serta mampu menjunjung tingi martabat bangsa, aspek keamanan juga mendapatkan perhatian yang ditekankan dalam peraturan lalu lintas dan angkutan jalan. Selain itu di dalam undang-undang ini juga ditekankan terwujudnya etika berlalu lintas dan budaya bangsa melalui upaya pembinaan, pemberian bimbingan, dan pendidikan berlalu lintas sejak usia dini serta dilaksanakan melalui program yang berkesinambungan".

Untuk mewujudkannya diperlukan kesadaran dan disiplin masyarakat dalam berlalu lintas. Salah satu upaya untuk meningkatkan kesadaran dan disiplin berlalu lintas dapat dilakukan dengan penyebarluasan pengertian dan pengetahuan hukum lalu lintas secara praktis dan mudah di mengerti oleh masyarakat luas.

Tingkat disiplin dan pemahaman terhadap peraturan dan sopan santun berlalu lintas yang rendah dari para pemakai jalan merupakan hal yang perlu mendapatkan perhatian khusus dalam upaya pemecahannya untuk mengatasi permasalahan di bidang lalu lintas. Berbagai upaya telah dilaksanakan oleh pemerintah untuk memperbaiki kondisi lalu lintas di Indonesia, namun masih belum mampu mengimbangi perkembangan lalu lintas yang begitu pesat.

Sebagai gambaran tentang data kecelakaan lalu lintas yang telah terjadi pada tahun 2017-2018 di Resor Gianyar sebanyak 1.031 kali mengakibatkan 228 jiwa mati, 306 luka berat, 1.162 luka ringan. Jika ditabelkan seperti dibawah ini

Tabel 1. Data Kecelakaan Lalu Lintas Tahun 2017 dan 2018

\begin{tabular}{|c|c|c|c|c|c|c|c|c|c|c|c|}
\hline \multirow[t]{2}{*}{ No } & \multirow[t]{2}{*}{ Bulan } & \multirow{2}{*}{$\begin{array}{l}\text { Laka } \\
2017\end{array}$} & \multicolumn{3}{|c|}{ Korban } & \multirow{2}{*}{$\begin{array}{l}\text { Laka } \\
2018\end{array}$} & \multicolumn{3}{|c|}{ Korban } & \multicolumn{2}{|c|}{ TREND } \\
\hline & & & MD & LB & LR & & MD & LB & LR & Selisih & $\%$ \\
\hline 1 & Januari & 46 & 15 & 25 & 37 & 36 & 9 & 15 & 37 & Turun & $28 \%$ \\
\hline 2 & Pebruari & 36 & 8 & 18 & 30 & 47 & 4 & 18 & 55 & Naik & $-23 \%$ \\
\hline 3 & Maret & 44 & 8 & 23 & 39 & 38 & 13 & 6 & 40 & Turun & $16 \%$ \\
\hline 4 & April & 30 & 9 & 7 & 36 & 42 & 8 & 13 & 49 & Naik & $-29 \%$ \\
\hline 5 & Mei & 29 & 8 & 3 & 36 & 40 & 9 & 14 & 41 & Naik & $-28 \%$ \\
\hline 6 & Juni & 35 & 10 & 1 & 44 & 49 & 14 & 10 & 59 & Naik & $-29 \%$ \\
\hline
\end{tabular}




\begin{tabular}{llllllllllll}
\hline 7 & Juli & 48 & 6 & 5 & 73 & 34 & 5 & 13 & 59 & Turun & $41 \%$ \\
\hline 8 & Agustus & 57 & 9 & 8 & 79 & 58 & 14 & 23 & 56 & Naik & $-2 \%$ \\
\hline 9 & September & 60 & 10 & 2 & 84 & 60 & 15 & 18 & 65 & 0 & $0 \%$ \\
\hline 10 & Oktober & 43 & 9 & 12 & 54 & 44 & 7 & 16 & 47 & Naik & $-2 \%$ \\
\hline 11 & Nopember & 31 & 6 & 11 & 27 & 46 & 13 & 15 & 43 & Naik & $-33 \%$ \\
\hline 12 & Desember & 35 & 6 & 18 & 32 & 43 & 13 & 12 & 42 & Naik & $-19 \%$ \\
\hline Jumlah & $\mathbf{4 9 4}$ & $\mathbf{1 0 4}$ & $\mathbf{1 3 3}$ & $\mathbf{5 7 1}$ & $\mathbf{5 3 7}$ & $\mathbf{1 2 4}$ & $\mathbf{1 7 3}$ & $\mathbf{5 9 1}$ & Naik & $\mathbf{- 8 \%}$ \\
\hline
\end{tabular}

Sumber : Resor Gianyar 2019

Jika diperhatikan, jalan merupakan tempat orang-orang untuk menuju ke suatu tujuan, karena berbagai kepentingan dengan menggunakan berbagai kendaraan atau pejalan kaki. Jalan menjadi suatu sarana vital dalam roda perekonomian masyarakat, namun di balik itu jalan juga merupakan suatu ladang pembantaian manusia yang berakibat kematian yang luar biasa besarnya. Bertitik tolak dari data kecelakaan di atas kita dihadapkan pada fakta-fakta sebagai berikut : Dari data 2 tahun berjalan didapatkan angka kecelakaan lalu lintas berakibat korban meninggal dunia sebanyak 228 jiwa meninggal dunia, 306 luka berat, 1.162 luka ringan. Jumlah kecelakaan lalu lintas yang terjadi sebanyak 1.031 kali.

Untuk menekan angka kecelakaan lalu lintas yang sangat tinggi, upaya ke depan diarahkan pada penanggulangan secara komprehensif yang mencakup upaya pembinaan, pencegahan, pengaturan dan pencegahan hukum.

Dari kenyataan tersebut di atas maka penting dan relevan untuk dikaji secara ilmiah mengenai tanggung jawab pidana bagi para pelaku dalam peristiwa kecelakaan lalu lintas yang sering terjadi di masyarakat yang kadang-kadang melibatkan keluarga kita, saudara kita, dan masyarakat kita untuk nantinya dapat diketahui oleh seluruh masyarakat sebagai pegangan dan suluh dalam perilakunya sehari-hari.

\section{Metode Penelitian}

Penelitian yang dipakai adalah yuridis empiris sebab dalam "penelitian ini disamping berdasarkan teori-teori yang ada kemudian juga dibandingkan dengan penelitian berdasarkan wawancara dan data di lapangan". ${ }^{1}$ Dalam penelitian ini digunakan pendekatan sosiologis, pendekatan perundang-undangan (statue approach), pendekatan konseptual (conseptual approach) dan pendekatan kasus (case approach).

Data yang dipakai ada dua jenis penelitian hukum empiris yaitu data primer dan data sekunder. Data primer merupakan data yang diperoleh dari lapangan melalui wawancara. Data sekunder diperoleh melalui penelitian kepustakaan yang berupa bahan hukum primer, sekunder dan tersier. Teknik analisis yang digunakan dalam penelitian ini adalah analisis deskriptif kualitatif.

1Sunggono Bambang, 2007, Metodelogi Penelitian Hukum, PT. Raja Grafindo, Jakarta, hal. 44. 


\section{Hasil dan Pembahasan}

\subsection{Akibat Hukum Bagi Pelaku Dalam Kecelakaan Lalu Lintas Yang Korbannya Meninggal Dunia}

Dalam peristiwa kecelakaan lalu lintas sudah tentu melibatkan satu atau beberapa kendaraan yang masing-masing dikemudikan oleh seseorang pengemudi. Mereka yang terlibat dalam peristiwa kecelakaan lalu lintas sudah barang tentu harus dapat mempertanggung jawabkan segala perbuatannya serta segala akibat yang ditimbulkan dalam peristiwa tersebut.

Menurut Moeljatno, ada suatu asas hukum yang menyatakan “Tidak dipidana jika tidak ada kesalahan". ${ }^{2}$ Asas ini tidak tersebut dalam hukum tertulis namun ada dalam hukum tak tertulis yang mana asas tersebut diakui di Indonesia. Jadi seseorang tidak dapat dipersalahkan atau dijatuhi hukuman pidana jika tidak didahului oleh perbuatan bersalah yang dilakukan olehnya.

Dalam penjelasan dari Pasal 44 KUHP tdisebutkan :

a. Kurang sempurna akalnya. Yang dimaksud dengan perkataan "akal" disini ialah : kekuatan pikiran, kecerdasan atau daya pikir. Jadi kurang sempurna akalnya misalnya : idiot, tuli bisu mulai ia lahir.

b. Yang termasuk sakit berubah akalnya misalnya : sakit gila, epilepsi dan bermacammacam penyakit jiwa lainnya.

c. Menurut A. Ridwan Halim, juga menyatakan : pelaku tidak dapat dipertanggung jawabkan perbuatannya dalam hal pelaku-pelaku tersebut:

1. Menderita penyakit jiwa atau berubah akalnya.

2. Tidak sempurna atau tidak normal pertumbuhan jiwanya (idiot). ${ }^{3}$

Rationya yang membebaskan orang-orang yang dimaksudkan dalam Pasal 44 KUHP itu dari tanggung jawab pidana adalah : mereka tidak dapat menyangka atau menilai akibat dari perbuatan mereka sehingga perbuatan tersebut pada umumnya mereka lakukan di luar kesadaran mereka. Karena itulah maka orang-orang seperti ini dianggap tidak mampu bertanggung jawab atas perbuatan mereka.

Jadi kaitannya antara kemampuan bertanggung jawab dalam peristiwa kecelakaan lalu lintas adalah : sepanjang para pelaku dalam tindak pidana kecelakaan lalu lintas tidak gila, idiot, hilang ingatan, maka ia dapat dipertanggung jawabkan perbuatannya secara hukum.

Dalam rumpun hukum pidana yang menjadi subyek hukum dalam hukum pidana adalah orang. Dalam hal ini orang yang secara hukum mampu bertanggung jawab atas perbuatan yang dilakukannya. Asalkan ia tidak gila, tidak idiot maka ia berpeluang untuk menjadi subyek hukum yang nantinya akan menerima sangsi hukum sesuai Undang-Undang yang berlaku. ${ }^{4}$

\footnotetext{
2 Moeljatno, 1993, Asas-Asas Hukum Pidana, Penerbit Rineka Cipta, Jakarta, hal.153.

${ }^{3}$ Ridwan Halim, 1995, Hukum Pidana Dalam Tanya Jawab, Ghalia Indonesia, Jakarta, hal.63.

${ }^{4}$ Lilik Mulyadi, 2007, Putusan Hakim Dalam Hukum Acara Pidana, PT Citra Aditya Bakti, Bandung, hal.126.
} 
Dalam kaitannya dengan peristiwa kecelakaan lalu lintas akan didapatkan beberapa kemungkinan sebagai berikut :

1. Dalam kecelakaan lalu lintas yang melibatkan dua buah kendaraan bermotor dimana yang satunya meninggal dunia maka akan terdapat satu subyek hukum yang masih hidup.

2. Jika melibatkan tiga buah kendaraan bermotor kemudian berakibat satu orang yang meninggal dunia diantara ketiganya tersebut maka akan didapatkan dua orang yang masih hidup yang berpeluang menjadi subyek hukum.

3. Jika dalam poin 2 di atas ternyata ada satu orang yang meninggal dunia namun yang meninggal tersebut bukan salah satu dari pengemudinya akan tetapi penumpang dari salah satu kendaraan maka akan didapatkan tiga orang pengemudi yang berpeluang menjadi subyek hukum. ${ }^{5}$

Melihat kemungkinan-kemungkinan yang terjadi seperti tersebut di atas maka bagaimanakah menentukan subyek hukum dalam peristiwa kecelakaan lalu lintas, korban meninggal dunia, seperti yang dikatakan oleh AKP Laksmi Trisnadewi Wieryawan, S.Ik, Kasat Lantas Polres Gianyar, Senin 5 Agustus 2019, Pukul: 11.00 Wita, menyatakan bahwa:

Terdakwa secara sah terlah terbukti melakukan tindak pidana karena kelalaiannya mengakibatkan kecelakaan lalu lintas yang mengakibatkan orang lain meninggal dunia dan luka ringan serta rusaknya kendaraan bermotor, oleh karena itu dipidana dengan pidana selama 8 (delapan) bulan.

Selanjutnya berdasarkan wawancara dengan IPTU I Ketut Nariawan, Kanit Laka Polres Gianyar, Senin 5 Agustus 2019, Pukul : 13.30 wita, yang mengatakan bahwa :

Tata cara berlalu lintas yang benar diatur dari Pasal 52 sampai dengan Pasal 87 Undang-undang Nomor 22 Tahun 2009 diantaranya : Mengatur tentang penggunaan jalur jalan, gerakan lalu lintas, tata cara melewati, tata cara berpapasan, tata cara membelok, tata cara memperlambat kendaraan, posisi kendaraan di jalan, jarak antara kendaraan, hak utama pada persimpangan.

Prioritas pertama penggunaan jalan untuk kelancaran lalu lintas, berhenti dan parkir, penggunaan komponen pendukung dan perlengkapan kendaraan bermotor. Peringatan dengan bunyi dan penggunaan lampu, penggiringan hewan dan penggunaan kendaraan tidak bermotor, kecepatan maksimum dan minimum, penetapan muatan terberat serta larangan penggunaan jalan.

Oleh karenanya menjadi sangat penting bagi penyidik untuk menguasai aturan-aturan yang tertuang dalam Pasal 54 sampai dengan Pasal 87 Undang-undang Nomor 22 Tahun 2009 untuk menentukan siapa diantara pengemudi yang terlibat telah melakukan suatu pelanggaran yang berakibat terjadinya kecelakaan tersebut. Oleh karena itu untuk menentukan subyek hukum dalam suatu peristiwa kecelakaan lalu lintas perlu dipahami hal-hal berikut :

1. Bahwa kecelakaan lalu lintas terbangun oleh satu atau beberapa pelanggaran.

${ }^{5}$ Ibid, hal. 130. 
2. Pelanggaran lalu lintas bisa berupa pelanggaran tingkah laku berlalu lintas yang dilakukan oleh seseorang.

3. Pelanggaran lalu lintas dapat berupa pelanggaran syarat-syarat teknis kendaraan bermotor (kelaikan jalan).

Apabila penyidik Polri yang menangani peristiwa kecelakaan lalu lintas ternyata hasil penyelidikan di TKP, dilanjutkan dengan pengumpulan bukti-bukti, keterangan saksisaksi serta hasil pengamatannya di TKP menyimpulkan bahwa si A telah melakukan pelanggaran terhadap tata cara berlalu lintas yang benar sampai akhirnya mengakibatkan kecelakaan lalu lintas tersebut maka penyidik akan menyimpulkan bahwa ialah subyek hukum atau sebagai Terdakwa dalam peristiwa tersebut.

Dalam suatu peristiwa kecelakaan lalu lintas berakibat korban meninggal dunia akan didapatkan kemungkinan-kemungkinan sebagai berikut :

1. Kemungkinan I adalah kekurang hati-hatian atau penyebab dari timbulnya kecelakaan disebabkan oleh korban yang meninggal dunia. Kapolres Gianyar mengistilahkan dengan (Terdakwa korban).

2. Kemungkinan II kekurang hati-hatian atau penyebab dari kecelakaan ada pada pengemudi yang masih hidup.

Yang dalam pengertiannya berarti karena kurang hati-hatinya, karena kelalaiannya, karena kealpaannya. Jadi siapa yang kurang hati-hati atau lalai dalam berlalu lintas maka dialah sebagai subyek hukum atau sebagai Terdakwa nya. Sehingga pilihan Terdakwa dapat ditujukan kepada ia yang meninggal dunia atau kepada ia yang masih hidup.

Selanjutnya berdasarkan wawancara penulis dengan IPTU I Ketut Nariawan, Kanit Laka Polres Gianyar, Senin 5 Agustus 2019, Pukul : 13.30 wita, berkaitan dengan subyek hukum dalam tindak pidana kecelakaan lalu lintas korban meninggal dunia dikemukakan sebagai berikut:

Bahwa unsur karena salahnya dalam Pasal 359 KUHP tidak cukup diartikan sebagai ketidak sengajaan belaka (culpa) namun selain tidak sengaja juga harus disertai kekurang hati-hatian atau perbuatan kelalaian dari seseorang. Oleh karena itu seseorang yang mengalami kecelakaan lalu lintas dimana lawannya meninggal dunia walaupun orang tersebut tidak sengaja menyebabkan lawannya meninggal sepanjang ia berhati-hati, tidak ada kelalaian atau kealpaan dan justru penyebab kecelakaan atau kekurang hati-hatian ada pada yang meninggal dunia maka seseorang yang hidup tersebut tidak bisa dihukum melanggar Pasal 359 KUHP. Karena ia tidak melanggar unsur yang ke-2 dari pasal tersebut yaitu unsur karena salahnya. Dan justru kekurang hati-hatian ada pada korban yang mati.

Lebih lanjut dikatakan oleh AKP Laksmi Trisnadewi Wieryawan, S.Ik, Kasat Lantas Polres Gianyar, Senin 5 Agustus 2019, Pukul: 11.00 Wita yaitu:

Dalam kecelakaan lalu lintas korban meninggal dunia tidaklah semua para pelaku yang masih hidup dalam peristiwa kecelakaan lalu lintas yang berakibat korban meninggal dunia dapat dihukum sesuai dengan Pasal 359 KUHP. Karena unsur karena salahnya dalam pasal tersebut bisa saja ada pada ia yang meninggal dunia. Dalam hal ini berkas tetap diajukan akan tetapi untuk meringankan tersangka maka dilampirkan surat pernyataan perdamaian dari kedua belah pihak. Tidak semua 
kekurang hati-hatian atau kelalaian ada pada mereka yang masih hidup. Jadi banyak dari sebagian masyarakat yang mengira bahwa jika ia terlibat kecelakaan lalu lintas dan lawannya mati maka ia pasti dihukum penjara. Padahal tidaklah semua demikian, harus dibuktikan dulu unsur kekurang hati-hatian tersebut ada pada siapa. Apakah yang lalai ada pada pelaku yang masih hidup atau yang lalai ada pada yang meninggal dunia.

Dari hasil wawancara tersebut di atas maka ada dua kemungkinan dalam suatu peristiwa kecelakaan lalu lintas berakibat korban meninggal dunia yaitu :

1. Subyek hukum ada pada pelaku yang masih hidup.

2. Subyek hukum ada pada pelaku yang meninggal dunia.

Yang dalam proses penyidikannya mengacu pada peraturan perundang-undangan yang berlaku dengan muara akhir hasil penyidikan yang juga pasti berbeda.

\subsection{Dasar Hukum Bagi Pelaku Dalam Pertanggung Jawaban Pidana Terhadap Kecelakaan Lalu Lintas}

Perjalanan sistem hukum di Negeri ini akan memberi gambaran akan kesadaran hukum masyarakat di dalamnya, demi mencapai keadilan dan kepastian hukum, tampaknya masih panjang dan berlaku, dan ini dapat dilihat makin maraknya kolusi terhadap tindakan aparat kepolisian terhadap pelanggaran yang terjadi di masyarakat, bahkan kalau melihat secara umum, masih terkatung-katungnya persoalan hukum yang ada seperti pemberantasan tindak pidana korupsi, BLBI bahkan yang paling parah sekarang ini, justru di LP (Lembaga Permasyarakatan) telah terjadi transaksi obat-obat terlarang, yang secara terang-terangan dilalukan oleh para "Nara Pidana" yang melibatkan langsung "sipir", dan semua ini memperkuat anggapan bahwa penegakan hukum bahwa supremasi hukum masih diliputi mendung.

Kenyataan diatas dibarengi dengan minornya keyakinan publik menyikapi citra aparat penegak hukum, baik ditingkat penyidikan, pengusutan dan penuntutan, selanjutnya sampai pada persidangan di Pengadilan, dan yang lebih parah adalah meningkatnya main hakim sendiri, demo yang berkepanjangan, setiap masyarakat yang merasa dirugikan atau dikebiri haknya langsung bertindak sendiri-sendiri tanpa mempergunakan jalur hukum yang resmi, dan ini membuktikan betapa minimnya "kesadaran hukum masyarakat".

Menurut Kunarto dalam bukunya "Merenungi Kritik Terhadap Polri" mengatakan bahwa terhadap kondisi sebagaimana penulis kemukakan diatas dipengaruhi oleh tiga hal :

1. Berkait dengan kemandirian para penegak hukum sendiri dalam memeriksa, mengadili ataupun pemberi bantuan hukum atas perkara-perkaranya yang sedang, sudah maupun yang akan ditangani.

2. Kerapuhan mental dari para penegak hukum diatas, seperti polisi, jaksa, dan hakim maupun pengacara dalam menolak KKN tidak bisa berbuat banyak, karena kekuasaanlah yang paling utama, dan hukum adalah masalah kedua.

3. Berkait dengan kemampuan secara individu serta pendidikan sehingga kinerja para penegak hukum dalam menangani setiap persoalan hukum masih jauh dari 
harapan untuk mendapatkan keadilan, bahkan ada kecendrungan hukum diperjual belikan. ${ }^{6}$

Berlaku atau tidaknya hukum dalam masyarakat, efektif atau tidaknya peraturan lalu lintas berdasarkan Undang-Undang Nomor 22 Tahun 2009 tentang Lalu Lintas dan Angkutan Jalan, bagi mereka yang mencari keadilan ditengah-tengah kehidupan sosial adalah merupakan sederetan pernyataan yang berkaitan dengan kaedah hukum itu sendiri. Kaedah hukum itu dibentuk berdasarkan kemauan masyarakat bersama untuk tertibnya berlalu lintas, oleh karena itu semua itu tergantung akan kesadaran masyarakat itu sendiri.

Jadi tujuan masalah kesadaran hukum itu adalah dimaksudkan sebagai kesadaran yang muncul pada dirinya sendiri, dan bukan adanya pengaruh atau paksaan orang lain yang didasarkan atas penilaian yang bersumber pada jiwa masyarakat itu sendiri secara manusiawi dan bukan paksaan, dan ini dapat diambil contoh : pemakaian "sabuk pengaman", harus dipahami bahwa dengan memakai "sabuk pengaman, adalah untuk keselamatan diri sendiri, apabila terjadi kecelakaan maka akan bisa terhindar dari akibat yang lebih parah. ${ }^{7}$

Demikian pula harus lahir dari kesadaran dirinya sendiri, seperti keharusan dan kewajiban untuk "memakai helm" dalam mengendarai sepeda motor, dan ini dapat dan sudah terbukti, apabila terjadi kecelakaan, maka bagi yang tidak mempergunakan "Helm" akan mendapat akibat lebih parah dari orang yang memakai "helm", oleh karena itu kesadaran hendaknya lahir dari dirinya sendiri terutama untuk mengantisipasi terjadinya kecelakaan.

Seperti kasus yang terjadi wilayah Hukum Resor Gianyar yang dilakukan terdakwa I Made Sutapa pada hari Minggu tanggal 18 Pebruari 2018, pukul 17.00 Wita di Jalan Umum Br. Kesian, Desa Lebih, Kec. Gianyar, Kab. Gianyar telah terjadi kecelakaan lalu lintas melibatkan sepeda motor Suzuki DK 5144 C dikemudikan oleh tersangka I Made Sutapa tabrakan dengan sepeda motor Honda DK 8405 KM dikemudikan oleh I Ketut Kembar Kartika membonceng Ni Made Sudiari. Kecelakaan lalu lintas tersebut terjadi karena kurang hati-hatinya tersangka I Made Supata saat mengemudikan sepeda motor Suzuki DK 5144 C datang dari arah utara ke selesatan tidak menjaga jarak aman, sehingga mengakibatkan terjadinya kecelakaan. Kecelakaan tersebut mengakibatkan pengemudi sepesa motor Honda DK 8405 KM mengalami luka-luka, sedangkan yang dibonceng sepeda motor Honda DK 8405 KM mengalami luka-luka dan meninggal dunia di RSUP Sanglah Denpasar, serta kerusakan pada sepeda motor Honda DK 8405 KM dan sepeda motor Suzuki DK 5144 C.

Berdasarkan kasus tersebut diatas, didapatkan bukti-bukti serta petunjuk adanya tindak pidana setiap orang yang mengemudikan Kendaraan Bermotor yang karena kelalaiannya mengakibatkan Kecelakaan Lalu Lintas dengan korban meninggal dunia atau mengalami luka berat, dan mengalami luka ringan sebagaimana yang dimaksud dalam Pasal 310 Ayat (4) Undang-Undang Republik Indonesia Nomor 22 Tahun 2009 jo Pasal 310 Ayat (3) Undang-Undang Republik Indonesia Nomor 22 Tahun 2009 dan pasal 310 Ayat (2) Undang-Undang Republik Indonesia Nomor 22 Tahun 2009.

\footnotetext{
${ }^{6}$ Kunarto, 2006, Merenungi Kritik Terhadap Polri, Buku 2, Cipta Manunggal, Jakarta, hal.50.

7 Soejono Soekanto, 2009, Pengantar Sosiologi Hukum, CV. Rajawali, Jakarta, hal.92.
} 
Untuk menghindari hal yang berkepanjangan, kesadaran hukum masyarakat dalam berlalu lintas dapat tercipta adanya kerjasama yang sinergi antara masyarakat dan aparat penegak hukum khususnya Kepolisian yang membidangi masalah lalu lintas, dengan mensosialisasikan Undang-Undang Nomor 22 Tahun 2009, dengan memberikan SIM dengan cukup ketat, dengan melihat pendidikan dan sifat serta tingkah laku secara psikologis, sehingga paling tidak dapat menekan angka kecelakaan akibat dari pelanggaran lalu lintas, apakah itu berupa rambu-rambu, atau marka jalan yang benar dengan memberikan tanda yang benar, apabila memarkir kendaraan di tepi jalan hendaknya memakai tanda segi tiga merah sebagai tanda ada kendaraan parkir, apakah karena ada kerusakan dan sebagainya, lebih-lebih yang pada saat ini volume kendaraan dalam lalu lintas cukup padat dan semakin meningkat.

Terkait dengan hal tersebut diatas dalam pertanggungjawaban terhadap kecelakaan lalu lintas diwilayah hukum Polres Gianyar seperti yang dijelaskan oleh AKP Laksmi Trisnadewi Wieryawan, S.Ik, Kasat Lantas Polres Gianyar, Senin 5 Agustus 2019, Pukul: 11.00 Wita, bahwa :

Ada beberapa hal yang dapat meringankan pelaku dalam pertanggung jawaban terhadap kecelakaan lalu lintas seperti : ada unsur ketidaksengajaan (alpa), belum pernah dihukum, ada perdamaian diantara para pihak, memberikan keterangan tidak berbelit-belit, adanya saksi yang meringankan, maka ancaman hukuman bisa lebih ringan.

Dengan demikian dapat dikatakan apabila terjadi kecelakaan atau pelanggaran lalu lintas berakibat meninggal dunia, pelaku dapat diber keringanan jika kecelakaan tersebut diakibatkan karena murni kealfaan, pelaku masih muda dan adanya perdamaian diantara korban dengan pelaku, dalam persidangan pelaku memberikan keterangan tidak berbelit-belit, serta adanya saksi meringankan.

\section{Kesimpulan}

Dari pembahasan keseluruhannya dapat digabungkan suatu kesimpulan berupa :

Akibat hukum bagi pelaku dalam kecelakaan lalu lintas yang korbannya meninggal dunia dipidana dengan hukuman penjara minimal 5 tahun. Sesuai Pasal 359 KUHP.

Pertimbangan hukum bagi pelaku dalam pertanggung jawaban pidana terhadap kecelakaan lalu lintas antara lain ada unsur ketidaksengajaan (alpa), belum pernah dihukum, ada perdamaian diantara para pihak, memberikan keterangan tidak berbelitbelit, adanya saksi yang meringankan, maka ancaman hukuman bisa lebih ringan.

\section{Daftar Pustaka}

Kunarto, 2006, Merenungi Kritik Terhadap Polri, Buku 2, Cipta Manunggal, Jakarta. Lilik Mulyadi, 2007, Putusan Hakim Dalam Hukum Acara Pidana, PT Citra Aditya Bakti, Bandung.

Moeljatno, 1993, Asas-asas Hukum Pidana, Penerbit Rineka Cipta, Jakarta.

Ridwan Halim, 1995, Hukum Pidana Dalam Tanya Jawab, Ghalia Indonesia, Jakarta.

Soejono Soekanto, 2009, Pengantar Sosiologi Hukum, CV. Rajawali, Jakarta.

Sunggono Bambang, 2007, Metodelogi Penelitian Hukum, PT. Raja Grafindo, Jakarta. 